\title{
Implementasi NodeMCU Dalam Home Automation Dengan Sistem Kontrol Aplikasi Blynk
}

\author{
Ilham Santoso ${ }^{1}$, Miftah Farid Adiwisastra², Bambang Kelana Simpony ${ }^{3}$, Deddy Supriadi ${ }^{4}$, \\ Dini Silvi Purnia ${ }^{5}$ \\ 1,2,3,4 Universitas Bina Sarana Informatika \\ e-mail: 1i.santoso024@gmail.com, 리 \\ 4deddy.dys@bsi.ac.id, \\ ${ }^{5}$ STMIK Nusa Mandiri \\ e-mail: dini.dlv@nusamandiri.ac.id
}

\begin{abstract}
Abstrak
Kemajuan teknologi sangat berkembang dengan pesat, hal ini sangat berpengaruh terhadap kehidupan manusia, dengan adanya teknologi pekerjaan sehari-hari menjadi lebih efisien. Jika seseorang sedang berada diluar rumah lalu lupa untuk mematikan perangkat elektronik maka orang tersebut harus kembali lagi ke rumah untuk mematikanya. Dengan adanya teknologi hal itu bisa dilakukan dari jarak jauh, teknologi tersebut dinamakan Internet of Things (IoT). IoT memungkinkan kita untuk dapat mengendalikan perangkat elektronik lainya dari jarak jauh menggunakan smartphone selama terhubung dengan internet. Penelitian ini bertujuan untuk membuat sebuah teknologi home automation berbasis loT dengan menggunakan metode penelitian PPDIOO. Home automation menggunakan beberapa perangkat seperti modul Arduino NodeMCU ESP8266, Relay, sensor DHT11, sensor MQ2, Buzzer dan aplikasi blynk. Dari hasil pengujian yang telah dilakukan home automation bisa mengontrol perangkat elektronik di rumah, dapat memonitoring suhu dan kelembaban suatu ruangan serta mendeteksi asap atau gas yang berpotensi menyebabkan kebakaran dan dengan sistem kontrol aplikasi blynk yang dapat dioperasikan dimana saja selama terhubung dengan internet.
\end{abstract}

Kata Kunci : Home Automation, Internet of Things, Blynk, PPDIOO.

\begin{abstract}
Technological advances are developing very rapidly, this is very influential on human life, with the technology of everyday work becoming more efficient. If someone is outside the house and forgets to turn off the electronic device, that person must return to the house to turn it off. With technology it can be done remotely, this technology is called the Internet of Things (IOT). IOT allows us to be able to control other electronic devices remotely using a smartphone as long as it is connected to the internet. The purpose of this study was to create an loT-based home automation technology using the PPDIOO research method. Home automation uses several devices such as the Arduino NodeMCU ESP8266 module, Relay, DHT11 sensor, MQ2 sensor, Buzzer, and blynk applications. The results of tests that had been carried out, home automation could control electronic devices at home, could monitor the temperature and humidity of a room, and detected smoke or gases that had the potential to cause fire and with a blynk application control system that could be operated anywhere as long as it is connected to the internet.
\end{abstract}

Keywords: Home Automation, Internet of Things, Blynk, PPDIOO

\section{Pendahuluan}

Perkembangan teknologi memicu pola pikir manusia untuk menciptakan inovasi-inovasi untuk memudahkan pekerjaan sehari hari demi kinerja yang lebih baik. Untuk menghidupkan atau mematikan lampu yang ada didalam rumah, maka penghuni rumah tersebut harus berjalan menuju saklar untuk membuka atau menutup sirkuit. Biasanya hal ini menimbulkan rasa malas seseorang untuk beranjak ketempat saklar tersebut berada. Ketika seseorang bepergian meninggalkan rumah, terkadang lupa untuk mematikan peralatan elektronik, seperti lampu, kipas 
angin, dan air conditioner (AC). Hal ini dapat memicu terjadinya kecelakaan rumah seperti kebakaran yang dipicu akibat korsleting listrik. Mengembangkan salah satu teknologi Internet Of Things (IoT) yang disebut dengan home automation (Satriadi, Wahyudi, \& Christiyono, 2019)

Home automation adalah salah satu teknologi otomatisasi yang mengacu pada pengendalian atau kontrol pada sebuah rangkaian elektronika dalam peralatan rumah, kantor dan lainnya (Sedayu, Yuniarti, \& Sanjaya, 2019). Dengan adanya teknologi home automation seseorang dapat mengontrol peralatan elektronik serta mengetahui suhu dan kelembaban udara yang ada didalam rumah bahkan dapat menerima notifikasi jika didalam rumah terdeteksi suhu panas dari asap yang berpotensi menyebabkan kebakaran dari jarak jauh dengan menggunakan smartphone yang terhubung ke internet.

Internet of Things (IoT) adalah sebuah konsep dimana konektifitas internet dapat bertukar informasi satu sama lainnya dengan benda-benda yang ada disekelilingnya. internet of things merupakan bagian dari sejarah perkembangan teknologi informasi dan komunikasi yang telah melahirkan teknologi seperti smart home, smart city dan wearables. Dengan adanya internet of things akan lebih mempermudah kegiatan manusia dalam melakukan berbagai aktifitas sehari-hari.Selain itu internet of things memiliki potensi untuk mengubah dunia seperti yangdilakukan oleh internet, bahkan mungkin lebih baik (Hidayatulloh, 2016). Menurut IEEE (Institute of Electrical and Electronics Engineers) : Internet of things (IOT) didefinisikan sebagai sebuah jaringan dengan masing-masing benda yang tertanam dengan sensor yang terhubung kedalam jaringan internet (Setiadi \& Abdul Muhaemin, 2018).

Penelitian sebelumnya yang membahas teknologi Internet of Things (loT) dalam paper yang berjudul "Internet Of Things Bandung Smart City" bertujuan untuk mengimplementasikan kemajuan teknologi kedalam sistem perkotaan atau yang disebut dengan smart city yang bertujuan untuk memudahkan masyarakat dalam mendapatkan informasi secara cepat (Hidayatulloh, 2016)

Penelitian selanjutnya yaitu dalam paper yang berjudul "Rancang Bangun
Prototipe Pengukuran dan Pemantauan Suhu, Kelembaban serta Cahaya Secara Otomatis Berbasis lot pada Rumah Jamur Merang" bertujuan untuk memudahkan para pembudidaya jamur untuk mengukur suhu rumah jamur, biasanya pembudidaya harus mengecek secara manual suhu ruangan hal itu tentu saja tidak efisien dan menghabiskan banyak waktu serta tenaga, maka dirancanglah sebuah teknologi untuk melakukan pengecekan suhu secara otomatis dengan menggunakan arduino uno dan sensor DHT11 sebagai sensor suhu (Hafiz \& Rahman, 2017).

Penelitian berikutnya dalam paper yang berjudul "Pembuatan Sistem Home Automation Berbasiskan Internet of Things" bertujuan untuk mengembangkan sistem smart home yang sudah ada. dari teknologi smart home yang sudah ada masih sedikit sistem yang terhubung dengan internet padahal banyak sekali keuntungan yang bisa didapat jika sistem tersebut terintegrasi dengan internet. Maka dibuatlah teknologi smart homeberbasis cloud Internet of Things, beberapa keuntungan dari sistem ini yaitu lebih aman, kemudahan mengimplementasikan sistem dibanyak perangkat dan platform (Limanta, Lim, Khoswanto, \& Siwalankerto, 2018).

Dalam penelitian ini kendali peralatan elektronik, pendeteksi suhu serta kelembaban dan pendeteksi asap akan dikontrol menggunakan aplikasi Blynk yang ada dismartphone berbasis NodeMCU yang telah dipasang modul WiFi ESP8266 sebagai media komunikasi dengan internet.

\section{Metode Penelitian}

\subsection{Metode Pengembangan loT}

Metode yang digunakan dalam penelitian ini merupakan metode pendekatan dari Cisco. Metode ini terdiri dari beberapa tahap, yaitu: Prepare, Plan, Design, limplement, Operate dan Optimize (PPDIOO)(Ulum et al., 2016).

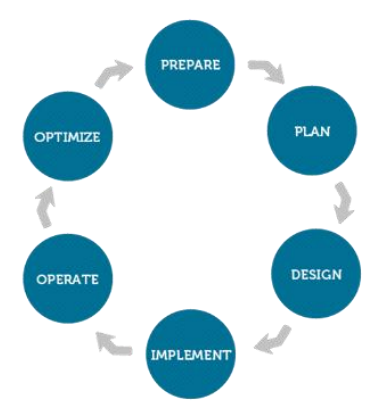

Gambar 1. Metode PPDIOO 
Sumber : (Ulum et al., 2016)

Prepare yaitu tahapan yang diawali dengan menganalisa dari beberapa jurnal, buku, artikel dan project yang telah ada yang berkaitan dengan penelitian serta mempersiapkan segala kebutuhan yang diperlukan. Selanjutnya tahapan plan yang diawali dengan mengidentifikasi spesifikasi kebutuhan hardware yang berkaitan dengan penelitian. Kemudian tahapan Design sebagai Kebutuhan awal yang telah ditentukan pada tahap Plan, selanjutnya membentuk desain arsitektur loT dan diagram alur kerja sistem sesuai dengan kebutuhan untuk diimplementasikan.

Setelah tahapan design selesai barulah tahapan Implement dimulai. Dalam tahapan ini semua komponen dan jaringan diimplementasikan sesuai dengan tahapan design yang telah dibuat. Pada tahapan operate sebagai pengujian akhir dari kesesuaian dengan tahapan sebelumnya dilakukan dengan pengujian berbentuk prototype (miniatur), hal ini dilakukan untuk memastikan apakah hardware dan sistem dapat berjalan dengan baik. Yang terkahir tahaoan Optimize bertujuan untuk mengidentifikasi dan memecahkan masalah sebelum masalah nyata timbul.

\subsection{Tools Pengembangan loT \\ 2.2.1. Arduino IDE}

Arduino IDE adalah editor yang digunakan untuk menulis program, mengcompile, dan upload program kedalam borad arduino. Lingkungan pengembangan arduino IDE terdiri atas text editor untuk menulis kode, message area, konsole text, toolbar dengan fungsi umum dan berbagai menu lainya (Hanan, Gunawan, \& Sumadiyasa, 2019).

Arduino adalah kit elektronik atau papan rangkaian elektonik yang bersifat open source yang didalamnya terdapat komponen utama yaitu chip mikrokontroler, dirancang untuk memudahkan penggunaan elektronik dalam berbagai bidang (Winardi \& Firmansyah, 2016)

IDE merupakan kepanjangan dari Integrated Development Enviroenment atau secara bahasa merupakan lingkungan terintegrasi yang digunakan untuk melakukan pengembangan. Program yang ditulis menggunakan arduino IDE disebut dengan sketch. Sketch ditulis dan disimpan dalam ekstensi ino.

\subsubsection{Blynk}

Blynk merupakan flatform sistem operasi Android maupun iOS sebagai kendali pada modul Arduino, Rapsberry Pi, ESP8266 dan perangkat sejenis lainya melalui internet (Sedayu et al., 2019). Aplikasi blynk ini sangat mudah digunakan meskipun baru menggunakanya, untuk berkomunikasi dengan board arduino blynk menggunakan sebuah kode yang disebut auth token. Kode tersebut akan dikirimkan melalui email yang telah terdaftar di blynk lalu dipasangkan kedalam kode program yang telah dibuat.

\section{Hasil Dan Pembahasan \\ 3.1. Perancangan Hardware \\ 3.1.1. NodeMCU ESP8266}

NodeMCU ini berfungsi sebagai mikrokontroller yang menjadi pusat kontrol dalam teknologi internet of things dan juga berfungsi sebagai tempat untuk mengupload program yang sudah dibuat

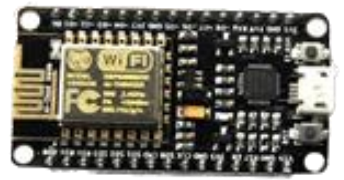

\section{Gambar 2. NodeMCU Esp8266 \\ Sumber : Penulis (2021)}

\subsubsection{Module Relay}

Relay ini berfungsi untuk menghidupkan dan mematikan arus listrik yang melewatinya, sehingga semua perangkat elektronik yang terhubung melalui relay akan menyala jika arus relay dalam keadaan hidup begitupun sebaliknya. Dalam penelitian ini perangkat elektronik yang terhubung akan digantikan menggunakan lampu, meskipun begitu konsep sistem dari smart home ini semuanya sama.

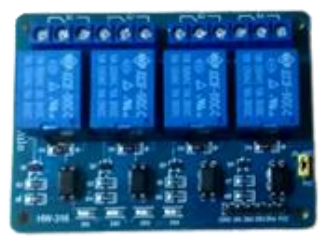

\section{Gambar 3. Relay 4 Channel Sumber : Penulis (2021)}

\subsubsection{Sensor DHT11}

Sensor DHT11 digunakan untuk mendeteksi suhu dan kelembaban ruangan, output dari DHT11 ini berupa angka yang 
akan ditampilkan secara realtime dengan menggunakan aplikasi Blynk.

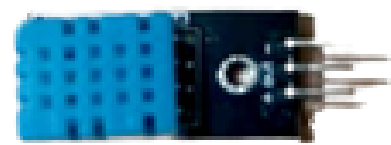

Gambar 4. Sensor DHT11

Sumber : Penulis (2021)

\subsubsection{Sensor MQ2}

Sensor MQ2 merupakan sensor gas monoksida yang berfungsi mengetahui keberadaan gas karbon monoksida(Rizki, Sara, \& Gapy, 2017). Sensor MQ2 digunakan untuk mendeteksi suhu panas dari asap dan mendeteksi adanya gas didalam ruangan yang bisa berpotensi kebakaran, hasil yang dikeluarkan dari sensorMQ2 ini berupa angka dari $0-1000$ yang akan ditampilkan secara real time dengan menggunakan aplikasi blynk. Jika nilai tersebut lebih dari 800 maka buzzer akan menyala

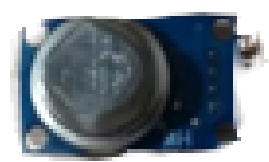

Gambar 5. Sensor MQ2

Sumber : Penulis (2021)

\subsubsection{Buzzer}

Buzzer berfungsi sebagai alarm untuk memberitahu bahwa ada bahaya yang sedang terjadi.

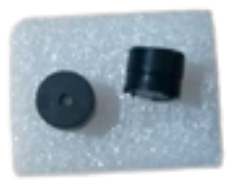

Gambar 6. Buzzer

Sumber : Penulis (2021)

\subsubsection{Breadboard}

Breadboard berfungsi sebagai tempat untuk menanamkan perangkat loT yang bersifat sementara artinya perangkat yang terpasang di breadboard bisa dilepas kembali.

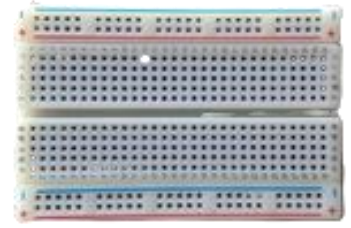

Gambar 7. Breadboard Sumber : Penulis (2021)

\subsubsection{Kabel Jumper}

Kabel Jumper digunakan sebagai penghubung antara nodeMCU dengan perangkat IoT lainya melalui breadeboard.

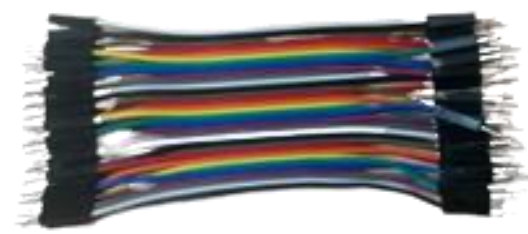

Gambar 8. Kabel Jumper

Sumber : Penulis (2021)

\subsubsection{Desain Skema Rangkaian loT}

Desain Skema rangkaian IoT berfungsi sebagai panduan dalam membuat suatu rangkaian elektronik.

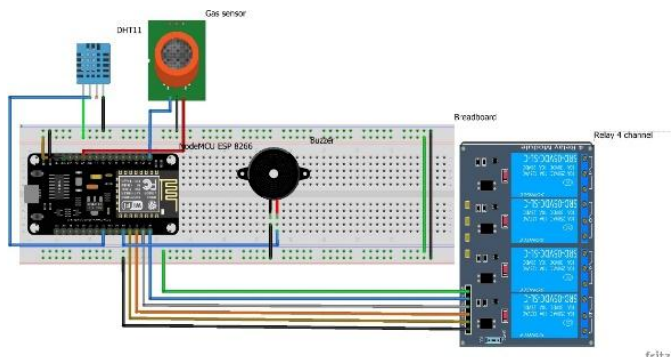

Gambar 8. Desain Skema Rangkaian loT Sumber : Penulis (2021)

\subsection{Perancangan Software}

\subsubsection{Konfigurasi Aplikasi Blynk}

Aplikasi blynk berfungsi sebagai aplikasi pengontrol perangkat loT, aplikasi ini bisa didwonload secara gratis di apps store untuk pengguna iphone dan play store untuk pengguna android. Dalam aplikasi ini sudah disediakan energy default sebesar 2000 energy. setiap widget box mempunyai nilai energy yang berbedabeda, jika energy yang dimiliki tidak mencukupi untuk membuat beberapa widget box maka diharuskan membeli energy tambahan.

Setelah aplikasi blynk berhasil didownload dan diinstall kedalam smartphone, selanjutnya membuat dan 
memberi nama project baru dan memilih salah satu module arduino yang digunakan, token blynk akan dikirimkan melalui email aktif yang terdaftar setelah mengklik email all dalam aplikasi blynk. Selanjutnya membuat widget box sesuai kebutuhan. Dalam penelitian ini terdapat dua jenis widget box yang digunakan yaitu:

a. Button

Button digunakan untuk pengontrol on/off relay, ketika button berada diposisi off maka relay akan mati, begitupun sebaliknya. Untuk menggunakan button cukup melakukan drag and drop kedalam project kosong yang telah dibuat sebelumnya. Setalah itu mengkonfigurasi button untuk menentukan pin yang akan digunakan sesuai dengan skema rangkaian yang telah dibuat.

b. Gauge

Gauge digunakan untuk memantau hasil input dari sensor MQ2 dan DHT11, Untuk menggunakan gauge cukup melakukan drag and drop kedalam project yang telah dibuat sebelumnya.Setelah

mengkonfigurasi gauge untuk menentukan pin yang akan digunakan sesuai dengan skema rangkaian yang telah dibuat. Setelah semua widget dibuat maka hasilnya seperti gambar dibawah ini :

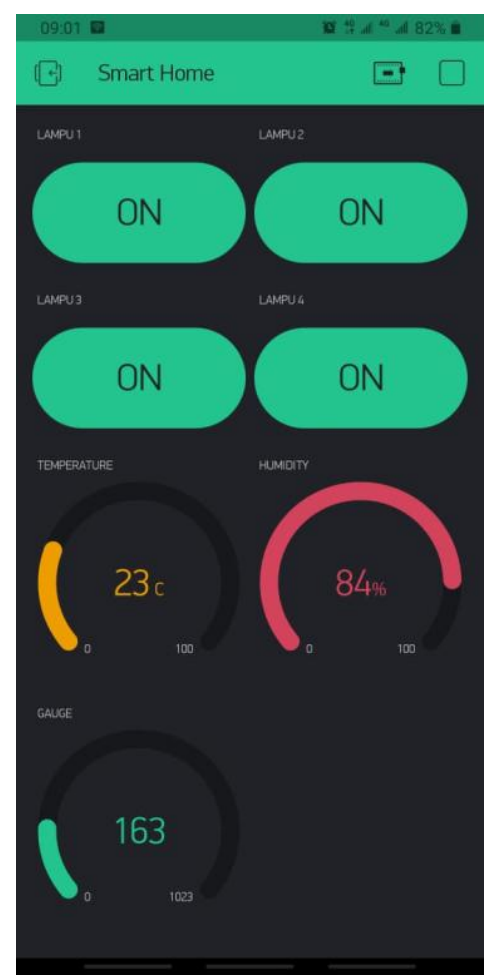

Gambar 9. Widget Blynk Sumber : Penulis (2021)

\subsubsection{Membuat Kode Program loT}

Aplikasi yang digunakan dalam membuat program loT ini adalah arduino IDE. Aplikasi ini bisa didownload secara gratis melalui website resminya. Dengan menggunakan aplikasi ini sudah banyak tersedia library perangkat loT, sehingga memudahkan pengguna dalam membuat baris program. Sebelum membuat kode program, board manager arduino IDE harus disesuaikan dengan module yang digunakan. sensor MQ2, DHT11 dan aplikasi blynk mempunyai library masingmasing yang harus diupload kedalam arduino IDE, hal ini dimaksudkan supaya perangkat dapat berjalan dengan baik dan memudahkan dalam proses upload kode program kedalam module arduino. Berikut adalah baris kode program home automation :

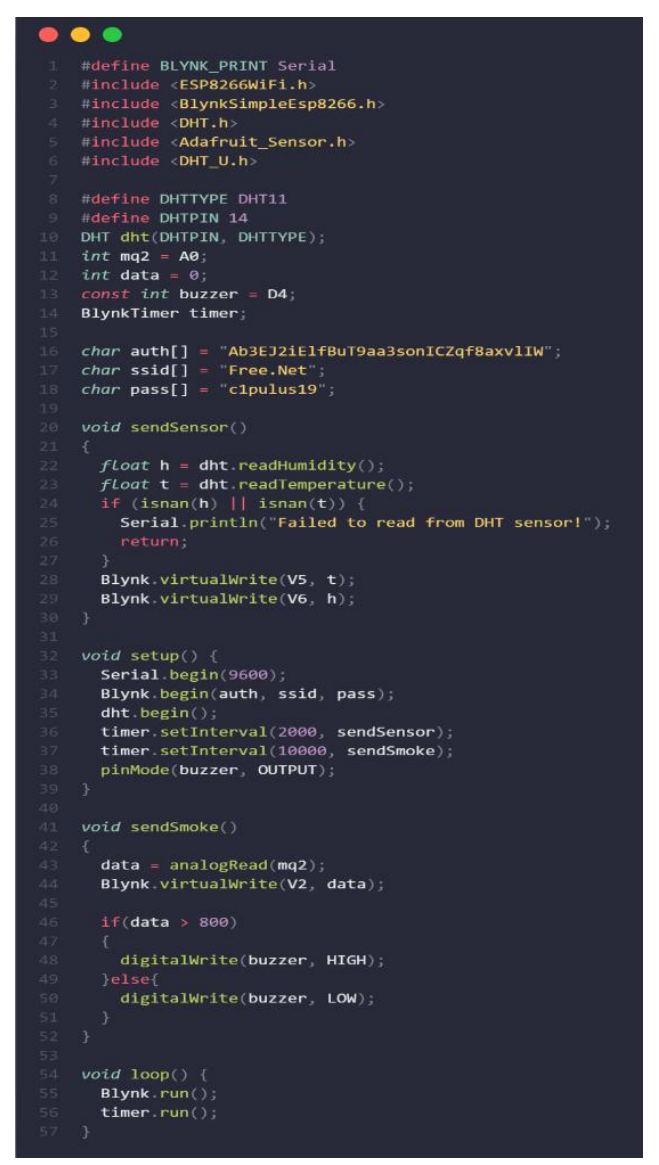

Gambar 10. Kode Program Home Automation Sumber : Penulis (2021) 


\subsection{Menyusun Rangkaian loT}

Dalam menyusun rangkaian loT berpatok pada tahapan design rangkaian yang telah dibuat, hal ini bertujuan supaya rangkaian yang telah dirancang tidak jauh berbeda dengan hasil rangkaian. Berikut adalah susunan rangkaian loT:

a. NodeMCU

NodeMCU mempunyai beberapa pin yang fungsinya berbeda-beda, diantaranya yaitu VIN digunakan sebagai output power sebesar 5V, 3.3V digunakan sebagai output power sebesar 3.3V, GND atau gorund digunakan sebagai kutub negatif, dan terdapat beberapa pin analog input serta pin digital yang digunakan sebagai input dan output. NodeMCU ditanamkan kedalam port yang sudah ada di breadboard. Supaya saluran positif dan negatif yang ada di breadboard teraliri, maka gunakan kabel jumper menyambungkan pin VIN nodeMCU disambungkan ke saluran positif breadboard dan pin GDN nodeMCU disambungkan ke saluran negatif breadboard.

b. Relay

Relay yang digunakan untuk tugas akhir ini meggunakan relay empat channel, terdapat 6 pin yaitu pin VCC, GND dan pin IN untuk masing masing channel relay. Pin VCC relay dihubungkan ke saluran positif breadboard, pin GND dihubungkan ke saluran negatif breadboard, sedangkan untuk pin IN dihubungkan ke pin digital nodeMCU yang berbeda. Pin IN1 dihubungkan ke pin D0, Pin IN2 dihubungkan ke pin D1, Pin IN3 dihubungkan ke pin D2, Pin IN4 dihubungkan ke pin D3.

c. Sensor DHT11

Sensor DHT11 mempunyai dua tipe pin, yaitu tiga pin dan empat pin. Dalam tugas akhir ini sensor DHT11 yang digunakan yaitu tipe tiga pin dimana terdapat pin positif, negatif dan out. Pin positif dari sensor DHT11 dihubungkan ke saluran positif breadboard, pin negatif dari sensor DHT11 dihubungkan ke saluran negatif breadboard, sedangkan pin out dari sensor DHT11 dihubungkan ke pin D5.

d. Sensor MQ2
Sensor MQ2 mempunyai empat pin, yaitu pin VCC, GND, AO dan DO. Pin VCC disambungkan ke saluran positif breadboard, pin GND disambungkan ke saluran negatif breadboard, karena output dari sensor ini berupa tegangan analog maka pin yang digunakan adalah pin $A O$, pin $A O$ ini dihubungkan ke pin $A O$ yang ada pada nodeMCU.

e. Buzzer

Buzzer mempunyai dua pin, yaitu pin positif dan pin negatif, buzzer akan menyala jika output yang dihasilkan sensor MQ2 melebihi angka 800, data ini akan dikirimkan melalui pin D4 yang ada pada nodeMCU. Jadi pin positif dari buzzer dihubungkan ke pin D4 nodeMCU dan pin negatif dari buzzer dihubungkan ke saluran negatif breadboard.

Sehingga semua susunan rangkain loT seperti pada gambar dibawah ini :

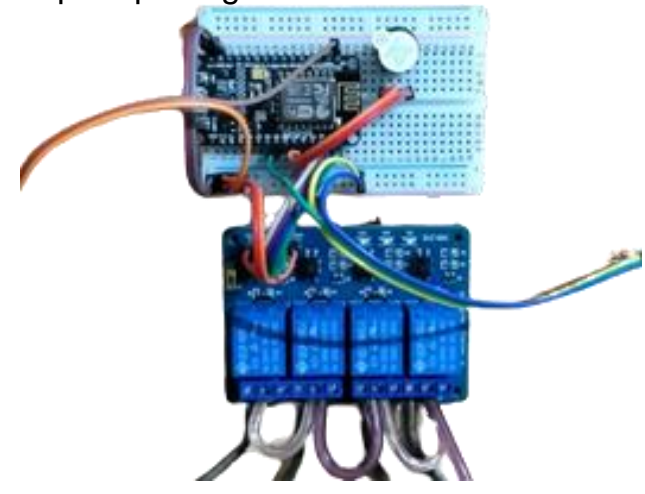

Gambar 11. Susunan Rangkaian loT Bagian Depan

Sumber : Penulis (2021)

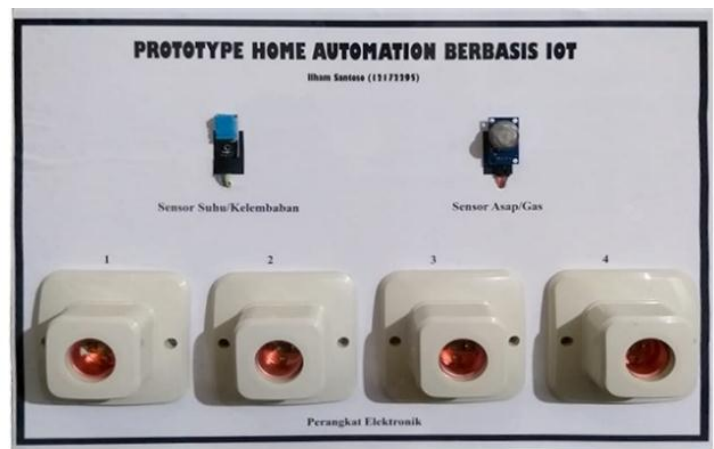

Gambar 12. Susunan Rangkaian loT Bagian Belakang Sumber : Penulis (2021)

\subsection{Pengujian Perangkat}


Pada tahapan ini semua perangkat yang dilakukan uji coba meliputi hardware dan software. Pengujian hardware dilakukan dengan memperhatikan perangkat dapat terhubung dengan aplikasi blynk dengan internet serta berjalan dengan baik sesuai dengan desain yang telah dibuat sebelumnya. Berikut gambar pengujian hardware:

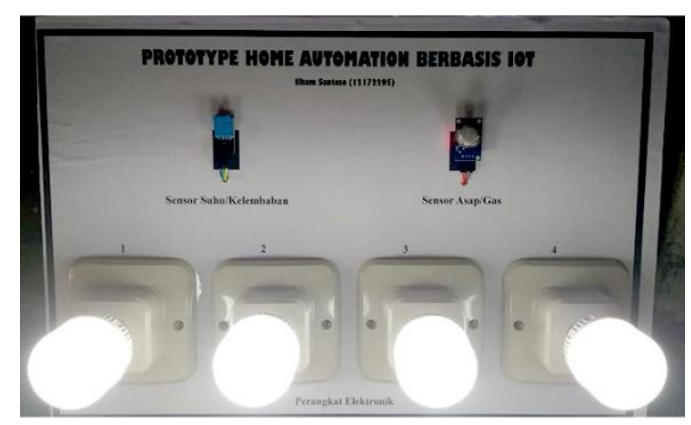

Gambar 13. Pengujian Perangkat Hardware Sumber : Penulis (2021)

Sedangkan untuk pengujian software dilakukan dengan memperhatikan aplikasi blynk dapat terhubung dengan perangkat dengan internet, widget box button bisa menghidupkan dan mematikan lampu melalui relay, sedangkan gauge bisa menampilkan angka hasil deteksi sensor. Berikut gambar pengujian software

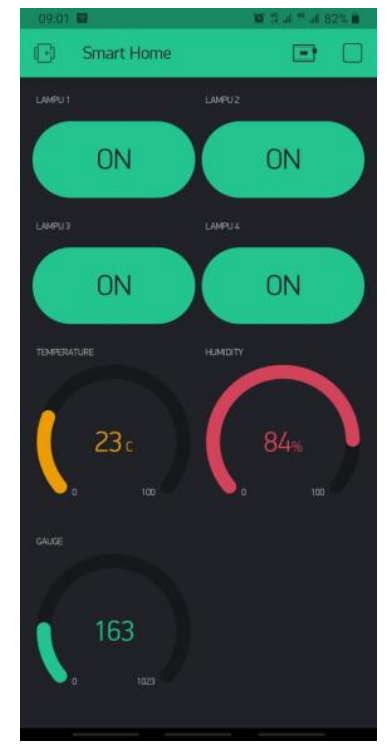

Gambar 13. Pengujian Perangkat Software Sumber : Penulis (2021)

Setelah pengujian selanjutnya tahap optimize yaitu mengidentifikasi masalah yang akan timbul dan meminimaliris error yang terjadi. Masalah yang sering terjadi yaitu tidak stabilnya koneksi internet, akibatnya peranglat loT tidak tidak dapat terhubung dengan aplikasi blynk begitupun sebaliknya, hal tersebut ditandai dengan titik berwarna merah yang ada dibagian header aplikasi blynk. Selain itu penyebab tidak stabilnya koneksi internet adalah perintah yang dikirimkan oleh aplikasi blynk kepada perangkat loT terjadi delay. Untuk mengatsi hal tersebut, koneksi dan jaringan internet harus dipastikan stabil, ditempatkan ditempat yang terbuka.

\section{Kesimpulan}

Berdasarkan hasil pengembangan dan pengujianya diperoleh kesimpulan Cara kerja dari home automation adalah menghidupkan dan mematikan perangkat elektronik dengan cara memutuskan aliran listrik yang terhubung melalui relay, mendeteksi suhu dan kelembaban ruangan secara real time serta jika ada asap atau gas yang berpotensi menyebabkan kebakaran terdeteksi maka alarm akan berbunyi. Semua perangkat home automation dikendalikan dengan aplikasi blynk. Dengan adanya teknologi home automation berbasis loT ini, diharapkan lebih dapat memudahkan masyarakat di kehidupan sehari-hari dalam mengendalikan perangkat elektronik dirumahnya masing-masing demi kinerja lebih baik.

\section{Referensi}

Hafiz, A., \& Rahman, A. (2017). Rancang Bangun Prototipe Pengukuran Dan Pemantauan Suhu, Kelembaban Serta Cahaya Secara Otomatis Berbasis lot Pada Rumah Jamur Merang. Jurnal Karya IImiah Teknik Elektro, 2(3), 51-57.

Hanan, Gunawan, A. A. N., \& Sumadiyasa, M. (2019). Water level detection system based on ultrasonic sensors HC-SR04 and Esp8266-12 modules with telegram and buzzer communication media. Instrumentation Mesure Metrologie, 18(3), 305-309. https://doi.org/10.18280/i2m.180311

Hidayatulloh, S. (2016). Internet of Things Bandung Smart City. Jurnal Informatika, 3(2), 164-175.

Limanta, G. M., Lim, R., Khoswanto, H., \& Siwalankerto, J. (2018). Pembuatan 


Sistem Home Automation
Berbasiskan Internet of Things. Jurnal
Teknik Elektro, 11(2), 60-65.
https://doi.org/10.9744/jte.11.2.60-65

Rizki, R. S., Sara, I. D., \& Gapy, M. (2017). Sistem Deteksi Kebakaran Pada Gedung Berbasis Programmable Logic Controller (Plc). Jurnal Karya IImiah Teknik Elektro, 2(3), 99-104.

Satriadi, A., Wahyudi, \& Christiyono, Y. (2019). Perancangan Home Automation Berbasis NodeMCU. Transient, 8(1), 64-71. Retrieved from https://ejournal3.undip.ac.id/index.php /transient/article/view/22648

Sedayu, A., Yuniarti, E., \& Sanjaya, E. (2019). Rancang Bangun Home Automation Berbasis Raspberry Pi 3 Model B dengan Interface Aprlikasi Media Sosial Telegram sebagai Kendali. Al-Fiziya: Journal of Materials Science, Geophysics, Instrumentation and Theoretical Physics, 1(2), 42-47. https://doi.org/10.15408/fiziya.v1i2.92 54

Setiadi, D., \& Abdul Muhaemin, M. N. (2018). PENERAPAN INTERNET OF THINGS (IOT) PADA SISTEM MONITORING IRIGASI (SMART IRIGASI). Infotronik: Jurnal Teknologi Informasi Dan Elektronika, 3(2), 95. https://doi.org/10.32897/infotronik.201 8.3.2.108

Ulum, M. B., Studi, P., Informatika, T., Komputer, F. I., Unggul, U. E., \& Barat, J. (2016). DESAIN INTERNET OF THINGS ( IOT ) UNTUK OPTIMASI PRODUKSI. 69-73. Retrieved from https://media.neliti.com/media/publicat ions/268945-desain-internet-of-thingsiot-untuk-opti-a782b098.pdf

Winardi, S., \& Firmansyah. (2016). Menggunakan Android Berbasis Arduino Uno. E-Jurnal NARODROID,
2(1). 